RESEARCH ARTICLE

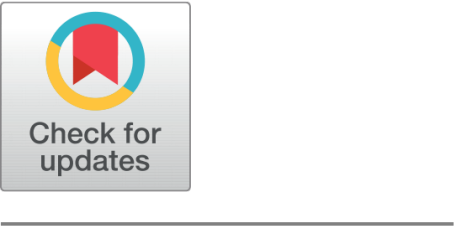

G OPEN ACCESS

Received: 16-04-2020

Accepted: 07-05-2020

Published: 09-06-2020

Editor: Dr. Natarajan Gajendran

Citation: Patel RJ, Bhaskaran L (2020) Orange peel as an inducer for Laccase production in a novel fungal strain peyronellaea pinodella BL-3/4 and optimization of its cultural parameters by single parameter approach. Indian Journal of Science and Technology 13(16): 1656-1667. https://doi.org/ 10.17485/IJST/v13i16.296

* Corresponding author. Rajeshri J Patel

Department of Microbiology, Shri M. M. Patel Institute of Science and Research, KSV, Gandhinagar, 382023, Gujarat, India.

Tel.: +91-9904435363

rajeshri.patel0417@gmail.com

Funding: None

Competing Interests: None

Copyright: (c) 2020 Patel, Bhaskaran. This is an open access article distributed under the terms of the Creative Commons Attribution License, which permits unrestricted use, distribution, and reproduction in any medium, provided the original author and source are credited.

Published By Indian Society for Education and Environment (iSee)

\section{Orange peel as an inducer for Laccase production in a novel fungal strain peyronellaea pinodella BL-3/4 and optimization of its cultural parameters by single parameter approach}

\author{
Rajeshri J Patel $^{1 *}$, Lakshmi Bhaskaran ${ }^{1}$ \\ 1 Department of Microbiology, Shri M. M. Patel Institute of Science and Research, KSV, \\ Gandhinagar, 382023, Gujarat, India. Tel.: +91-9904435363
}

\section{Abstract}

Objectives: Laccases are one of the ligninolytic enzymes with wide industrial applications hence objective of present study is to optimize laccase production in novel fungal strain Peyronellaea pinodella BL-3/4. Methodology: Fungal strains capable of oxidizing different lignin model compounds such as guaicol, syringaldazine and 2, 2'-Azino-bis (3ethylbenzthiozoline-6-sulphonic acid) were further tested for the laccase production in liquid media. 18s rRNA gene sequencing was performed to identify isolated novel fungal strain. Extracellular laccase activity from isolated fungal strain was optimized by the conventional 'single parameter at a time' approach. Parameters used for this study included inoculum size, temperature, $\mathrm{pH}$, agitation rate, lignocellulosic substrate, carbon source and nitrogen source. Findings: Among ten isolated laccase positive fungal strains, BL-3/4, exhibited maximum activity and morphological resemblance to Peyronellaea. 18s rRNA gene sequencing and phylogenetic analysis revealed that the isolated fungal strain is a novel one and identified as Peyronellaea pinodella BL-3/4. Optimization by single parameter approach leads to an 18 fold increase in laccase production by Peyronellaea pinodella BL-3/4. During the optimization of agro residues, orange peel acting as a substrate dramatically changed laccase production from 10.4 to $65.1 \mathrm{U} / \mathrm{mL}$. Novelty: No reports are available on Peyronellaea pinodella laccase activity and optimization of various factors affecting the laccase production. Orange peelings (an agro waste)as a substrate has increased the laccase production by six-fold in $P$. pinodella, this makes the fungi a better candidate for large scale production of laccase as well as for bioremediation, when compared to all other reported fungi.

Keywords: Ascomycetes; Optimization; Aromatic inducers; Laccase activity; Lignin model compounds 


\section{Introduction}

Lignin is naturally synthesized heterogeneous biopolymer with an aromatic backbone ${ }^{(1)}$. As it is recalcitrant in nature, enzymes of most microorganisms are not able to degrade it. Only ligninolytic enzymes collectively termed "lignin modifying enzymes" are able to degrade it. Lignin modifying enzymes can be classified as laccase, lignin peroxidase (LiP), manganese peroxidase $(\mathrm{MnP})$ and versatile peroxidase (VP).

Laccases (EC 1.10.3.2, para-diphenol: oxygen oxidoreductase) are the most extensively explored group of multi-copper oxidases. Owing to broad substrate specificity, laccases oxidize substituted phenolic compounds concomitant with the fourelectron reduction of molecular oxygen to water without releasing activated oxygen species ${ }^{(2)}$. Due to strong oxidative ability laccases was proven to be significantly useful in the degradation of synthetic dyes, printing and dyeing industry, bio-pulping in paper industry, conversion of aromatic compounds, detection of polyphenol in wine through laccase biosensor, removal of phenolics from wines and fruit juices, production of biogas and bioethanol, biofuel cell, bioremediation of the environment and detoxification of effluents ${ }^{(3-6)}$. Latest developments in basic and applied laccase research also emphasis on laccase-mediated bioremediation of pharmaceuticals, especially antibiotics ${ }^{(7)}$.

Laccases are widely distributed in plants, fungi, insects and bacteria ${ }^{(8)}$. In comparison with the bacterial laccases, fungal laccases have high redox potential ${ }^{(9)}$. Thus academic community has intensified the studies on laccase producing fungi in the recent years and optimized laccase production from a different group of fungi. Major laccase producing fungi described in literature belongs to class deuteromycete, ascomycetes as well as basidiomycetes ${ }^{(10)}$. Basidiomycetes especially white rot fungi are considered efficient laccase producers among all $^{(10,11)}$. However under natural static conditions, white-rot fungi requires extended period of incubation for efficient laccase production and cannot satisfy the demands of practical use in industry and biotechnology ${ }^{(12,13)}$.

In comparison with basidiomycete's fungi, laccases of ascomycetes are expressed at the early stages of fungal cultivation ${ }^{(12,14-18)}$ Some plant pathogenic species and soil ascomycete species were also reported for laccase production but not tested with different phenolic substrate as well as mediators, leaving it unclear if they are true laccases ${ }^{(19)}$. However, in harsh conditions laccases are unable to exhibit full efficiency ${ }^{(20)}$. Therefore, novel strains which can tolerate harsh conditions and give maximum enzyme production with minimum energy consumption are in huge demand.

Peyronellaea pinodella BL-3/4 (Synonym: Didymella pinodella), a novel fungal strain has not been explored by any scientists for improved laccase production through optimization of medium components. The main aim of the present study is to check the laccase producing ability of Peyronellaea pinodella BL-3/4. The optimization of nutritional parameters and cultivation conditions was also studied to increase production. The study was also carried out to see the role of various inducers in induction of the laccase enzyme.

\section{Materials and Methods}

\subsection{Chemicals}

2, 2'-azino-bis (3-ethylbenzothiazoline-6-sulfonic acid) (ABTS) and syringaldazine were purchased from Sigma (St. Louis M.O., U.S.A.). Lignin, bacteriological agar, guaicol, glucose, ammonium acetate and peptone were procured from Hi-Media (Mumbai, India). $\mathrm{KH}_{2} \mathrm{PO}_{4}, \mathrm{MgSO}_{4}, \mathrm{CaCl}_{2}, \mathrm{MnSO}_{4}, \mathrm{FeSO}_{4} \cdot 7 \mathrm{H}_{2} \mathrm{O}, \mathrm{CuSO}_{4}$ were procured from S.D. Fine chem. Limited (Mumbai, India).

\subsection{Screening, isolation and identification of fungal strain}

Soil samples were collected from the municipal solid waste dumping Site of Surat \& Ahmedabad (soil from surface \& soil beneath composted waste). Enrichment of lignin degrading fungi was performed according to the method reported earlier ${ }^{(17)}$. Isolated fungal cultures were screened for laccase production on composite selective mineral salt-glucose peptone (MS-GP) medium (pH 6.0) containing 5.0 g/L glucose, $5.0 \mathrm{~g} / \mathrm{L}$ peptone, $1.0 \mathrm{~g} / \mathrm{L} \mathrm{KH}_{2} \mathrm{PO}_{4}, 1.0 \mathrm{~g} / \mathrm{L}$ ammonium acetate, $0.01 \mathrm{~g} / \mathrm{L} \mathrm{MgSO}$ $0.01 \mathrm{~g} / \mathrm{L} \mathrm{CaCl} 2,0.001 \mathrm{~g} / \mathrm{L} \mathrm{MnSO} 4,0.001 \mathrm{~g} / \mathrm{L} \mathrm{FeSO} \cdot 7 \mathrm{H}_{2} \mathrm{O}, 0.0005 \mathrm{~g} / \mathrm{L} \mathrm{CuSO} 4,3 \%$ agar supplemented with different lignin model compounds. Lignin model compounds used for the study includes $0.1 \%$ ABTS, $0.1 \%$ syringaldazine and $0.06 \%$ guaicol. The correlation between positive reactions with different indicators was investigated ${ }^{(17)}$. Cultures were maintained on potato dextrose agar and stored at $4^{\circ} \mathrm{C}$. Colony morphology was examined on modified lignin mineral salt medium (MLM) after the $7^{\text {th }}$ day of incubation. Microscopic morphology was evaluated by mounting isolated fungus using lacto phenol cotton blue mount. 


\subsection{Genetic characterization of BL-3/4}

Genetic characterization of BL-3/4 was performed by partial gene sequencing of the 18s rRNA using ITS 1/ITS 4 primer (carried at Gujarat State Biotechnology Mission (GSBTM), Gandhinagar, Gujarat, India). The 18s rRNA gene sequence of BL-3/4 was deposited at the National Centre for Biotechnology Information (NCBI) repository. The deposited sequence was initially analyzed by Basic Local Alignment Search Tool (BLAST) and phylogenetic analysis was conducted using clustal W and MEGA 5 software. The evolutionary history was inferred using the neighbour-joining method. The tree was drawn to the scale, with branch lengths in the same units as those of the evolutionary distance used to infer the phylogenetic tree.

\subsection{Inoculation of fungal strain in production medium for submerged fermentation (SmF)}

SmF was carried out in the MS-GP production medium without lignin model compounds. The mycelial plugs (instead of spores) were used for inoculating the production media as the fungal strain P. pinodella BL-3/4 used in the present study produce spores in pycnidia. Two mycelial plugs (6mm diameter) from the edge of actively growing fungal cultures grown on MS-GP agar medium were used to inoculate the production medium. The fungal inoculated production media were incubated for 120 $\mathrm{h}$ at $30^{\circ} \mathrm{C}$ at $100 \mathrm{rpm}$.

\subsection{Laccase enzyme assay}

Extracellular laccase activity was determined using spectrophotometer with $2.5 \mathrm{mM}$ ABTS as a substrate. The reaction mixture contained $1.0 \mathrm{ml}$ of $2.5 \mathrm{mM}$ ABTS, $1.0 \mathrm{ml}$ of $0.1 \mathrm{M}$ sodium acetate buffer $(\mathrm{pH} 5.0)$ and $1.0 \mathrm{ml}$ of the enzyme. The oxidation of $\operatorname{ABTS}\left(\varepsilon=3.6 \times 10^{4} \mathrm{M}^{-1} \mathrm{~cm}^{-1}\right)$ was monitored by measuring the change in absorption at $420 \mathrm{~nm}$ for $5 \mathrm{~min}^{(21)}$. One unit of Laccase activity is defined as the amount of enzyme that oxidizes $1 \mu \mathrm{M}$ of ABTS per min.

\subsection{Optimization of cultural and nutritional parameters in submerged fermentation (single parameter optimization)}

Different agro wastes were screened to identify a suitable substrate for laccase production by $P$. pinodella BL-3/4 in submerged fermentation. Wheat bran, rice bran, sugarcane bagasse, orange peelings, rice husk and tobacco leaves were used as substrate. The effect of physical factors on the production of laccase was studied by changing the parameters like $\mathrm{pH}$, temperature and agitation. To study the effect of initial media $\mathrm{pH}$ on laccase production, the initial $\mathrm{pH}$ of the medium was adjusted to 4.0 to 8.0 at an interval of $0.5 \mathrm{pH}$, using $1 \mathrm{~N} \mathrm{HCl}$ and $1 \mathrm{~N} \mathrm{NaOH}$. Incubation temperature was studied between $20-40^{\circ} \mathrm{C}$, by incubating the culture flask at different temperatures like 20,25, 30, 35 and $40^{\circ} \mathrm{C}$. Agitation rate $(100,125,150,175$ and $200 \mathrm{rpm})$ and inoculum size $(1,2,3$ mycelial plugs up to 7 with a diameter of $6 \mathrm{~mm})$ were also varied to study their influence on laccase production. Effect of carbon sources on production of laccase enzyme by fungal strain were also studied by changing the carbon source [glucose $(0.5 \%)$, sucrose $(0.5 \%)$ and starch $(0.5 \%)]$. Sucrose was separately sterilized and added in to the medium prior to inoculation.

Effect of organic nitrogen source on laccase production was studied by using various nitrogen sources (peptone (0.5\%), yeast extract $(0.5 \%)$ and tryptone $(0.5 \%)$ ). The effects of different inorganic nitrogen sources were also studied by adding ammonium sulphate $(0.1 \%)$, ammonium chloride $(0.1 \%)$ and potassium nitrate $(0.1 \%)$ in to production medium. All experiments were performed in triplicates to obtain reproducible results. Inoculated media were incubated for $120 \mathrm{~h}$ to evaluate laccase production. Laccase was estimated using ABTS as a substrate ${ }^{(21)}$. Laccase estimation was performed in triplicates.

\subsection{Effect of inducers on Laccase production by fungal strain Peyronellaea pinodella BL-3/4}

To study the effect of inducers on laccase production by fungal strain P. pinodella BL-3/4, various aromatic compounds such as gallic acid, guaicol, catechol, pyrogallol, o-anisidine and $\mathrm{p}$-anisidine at a concentration of $0.5 \mathrm{mM}$ were added in different flasks having optimized medium. All aromatic compounds were dissolved in $50 \%$ alcohol. Effect of $1 \%$ absolute ethanol was also studied. All inducers were added in to optimized medium at the time of inoculum transfer. The flasks were incubated for 120 $\mathrm{h}$ at $30^{\circ} \mathrm{C}$ and laccase activity was measured using the protocol mentioned in laccase enzyme assay (Section 2.5). The control flask consists of $2 \mu \mathrm{M}$ copper sulphate along with optimized medium. Effect of copper ion concentration was evaluated by incorporating different concentrations of copper ion $(2-500 \mu \mathrm{M})$ into the production medium. The fermentation was carried out under the optimized condition for $120 \mathrm{~h}$. The laccase activities of all different sets were evaluated using the protocol mentioned in laccase enzyme assay. 


\subsection{Time course study}

Time course study of laccase production by $P$. pinodella BL-3/4 was studied in both unoptimized and optimized medium in $250 \mathrm{~mL}$ flasks inoculated with unoptimized ( 2 mycelial plugs) and optimized ( 5 mycelial plugs) and incubated at $30^{\circ} \mathrm{C}$ for 120 $\mathrm{h}$. The content of the flasks was harvested after every $24 \mathrm{~h}$ and assayed for laccase production using the protocol mentioned in enzyme assay (Section 2.5).

\subsection{Statistical analysis}

Three sets of readings were taken for all the experiments. Data, where appropriate, were subjected to two-way analysis of variance (ANOVA) followed by Tukey's multiple comparison test and Student's test using GraphPad Prism 8.3.1 (GraphPad Software Inc., San Diego, CA, USA). Effects of various parameters on laccase production were plotted using GraphPad Prism 8.3.1 Significance was accepted at $\mathrm{p} \leq 0.05$.

\section{Result and Discussion}

\subsection{Isolation, screening and Identification of fungal strain}

The laccase mediated catalysis can be extended to nonphenolic substrates by the inclusion of mediators. The most common synthetic mediators are 1-hydro-xybenzotriazole (HOBT), N-hydro-xyphthalimide (NHPI) and ABTS. The traditional use of Bavendamm's reaction for qualitative screening has mostly been replaced with synthetic phenolic compounds, such as guaicol $^{(22)}$ and $\mathrm{ABTS}^{(23)}$ as well as non phenolic compound syringaldazine as they are laccase specific ${ }^{(24,25)}$. The extracellular laccase activity of the isolated fungal strains was confirmed using MS-GP agar medium supplemented with guaicol, ABTS and syringaldazine. The positive isolates showed brown halo formation in guaicol supplemented plate, dark green halo in ABTS supplemented plate and dark pink coloration of colony edge in syringaldazine drop test. ABTS and syringaldazine are laccase specific substrates, therefore it is confirmed that the enzyme is a true laccase and not peroxidase enzyme. The fungal isolate which was designated as BL-3/4 gave a positive reaction with all three lignin model compounds like ABTS, guaicol and syringaldazine [ Figure 1]. The isolated strain BL-3/4 was selected for further studies. The colony of isolate BL-3/4, reaches an average of $5 \mathrm{~cm}$ diameter on the $7^{\text {th }}$ day of incubation on the MS-GP agar plate. The cultural characteristics of BL-3/4 are flat, brown with light brown pigmentation on the MS-GP agar media. Microscopic morphology showed septate hypha, ellipsoidal conidia formed in flask shaped pycnidia.
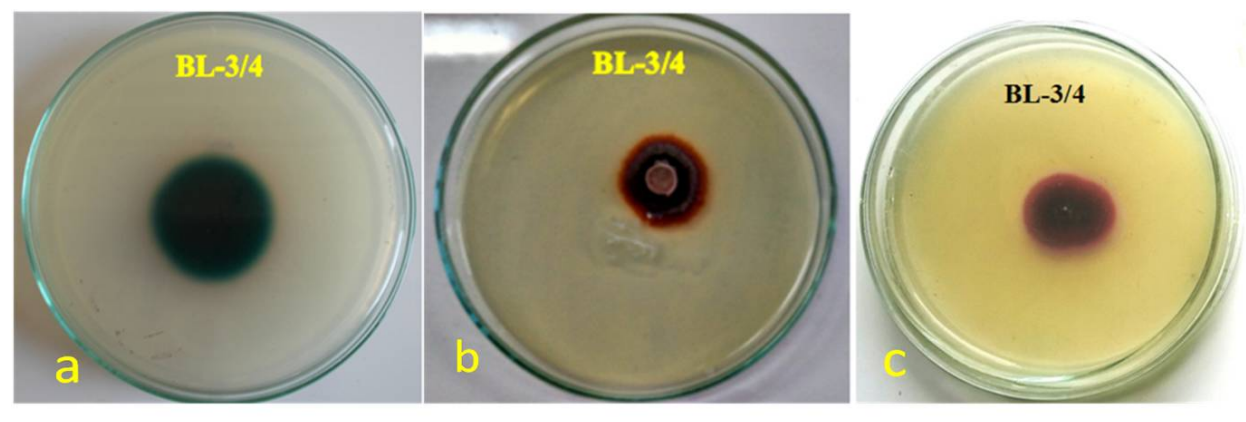

Fig 1. Qualitative screening of laccase production by BL-3/4 on MS-GP medium with different lignin model compounds. a. Green halo around colony indicates oxidation of ABTS, b. Reddish brown halo around colony indicates oxidation of guaicol and c. Dark pink halo around colony indicates oxidation of syringaldazine.

\subsection{Genetic characterization of BL-3/4}

The gene sequence deposited at the NCBI repository is accessible thorough Gene bank accession no., KT833620. The deposited sequence aligned using the BLAST tool and corresponding sequences data shows that isolate was $P$. pinodella. BLAST alignment data shows that maximum $98.69 \%$ sequence similarity as obtained with already deposited sequence of $P$. pinodella. Phylogenetic tree created with neighbour-joining method shows evolutionary history of deposited sequence with other aligned sequences ( Figure 2). The ability of different fungi to produce laccase has been reported but $P$. pinodella BL3/4 ability to produce laccase enzyme and its optimization has not been explored by any scientist. 


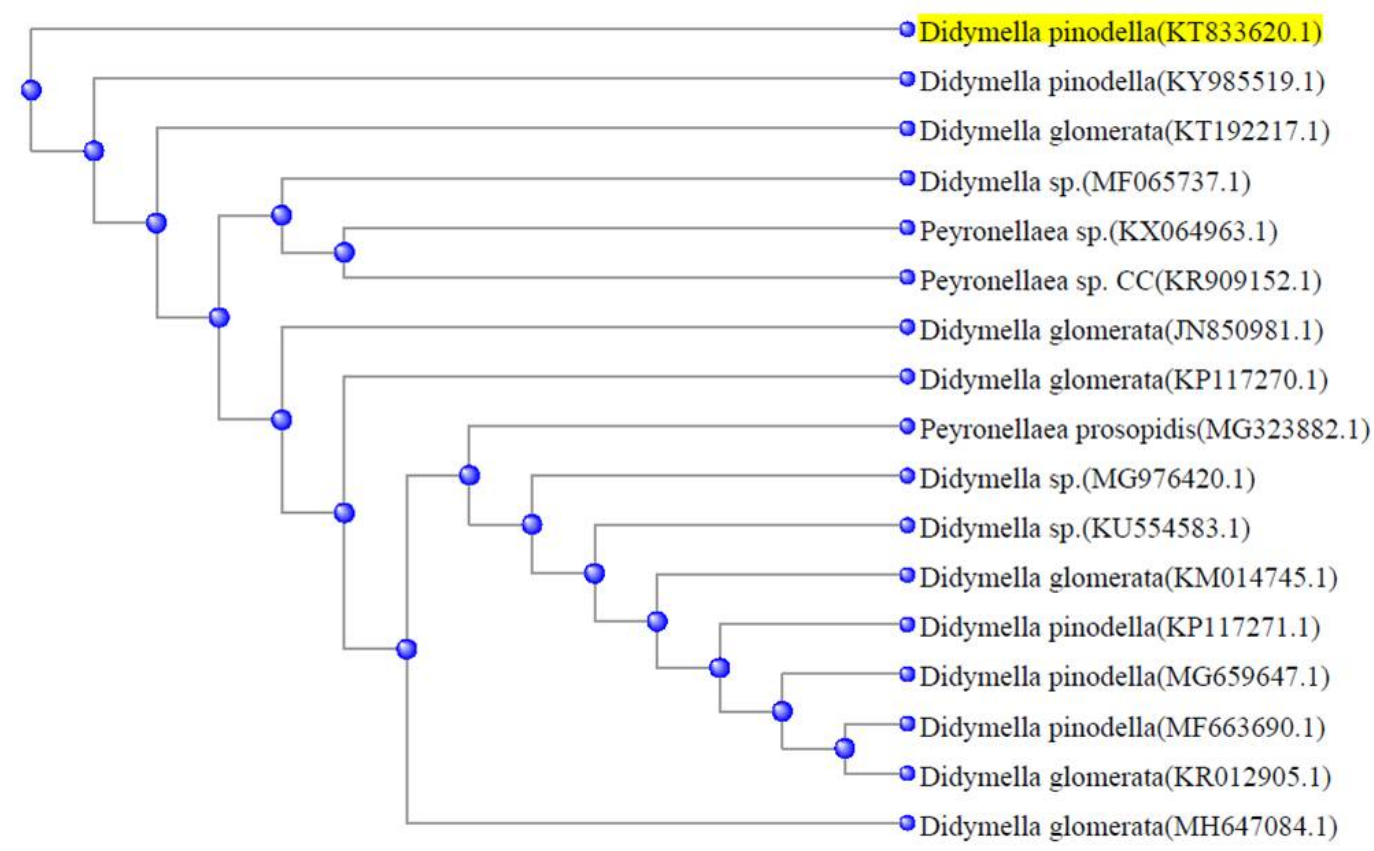

Fig 2. Phylogenetic relationship of BL-3/4 with other species ofPeyronellaea based on 18s rRNA gene sequencing.

\subsection{Optimization of various factors that influence maximum Laccase production}

\subsubsection{Optimization of inoculum Size}

Inoculum plays a significant role in enzyme production. Growth may not be initiated at a low level of inoculums whereas higher level may cause competitive inhibition for nutrients ${ }^{(26)}$. Thus, it is important to determine inoculums size. Inoculum size was optimized by inoculating production medium with 1-7 mycelial plugs (1,2,3 mycelial plugs up to 7 with a diameter of $6 \mathrm{~mm})$ from the edge of actively growing $120 \mathrm{~h}$ old fungal culture. Maximum laccase activity $(10.4 \mathrm{U} / \mathrm{mL})$ was obtained with 5 mycelium plugs on the $96 \mathrm{~h}$ of incubation [ Figure 3]. Laccase activity improves with an increase in inoculum size up to 5 mycelial plugs however further increase in the inoculum, laccase production was decreased due to nutrient depletion.

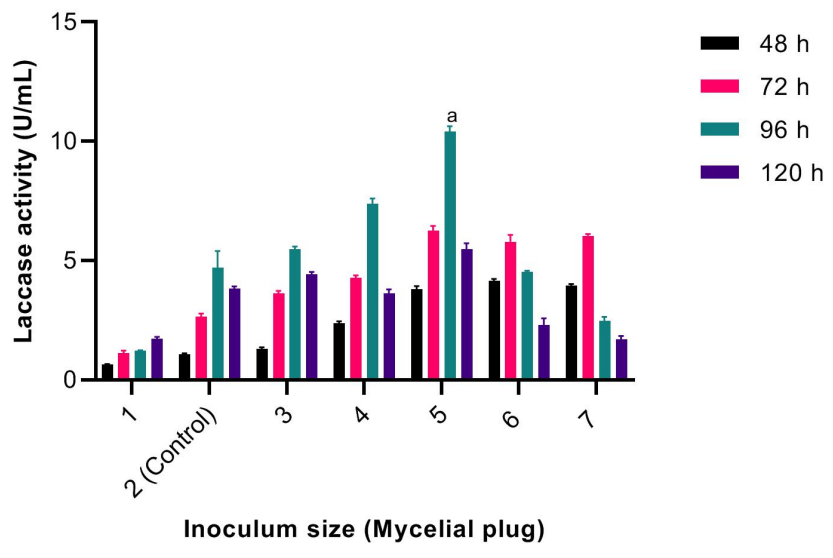

Fig 3. Effect of inoculum size on laccase production. ANOVA: $p$ value $=p<0.0001, p$ value summary based on Tukey's multiple comparison tests $={ }^{\text {a }}$ highly significant with respect to the control (2 Mycelial plugs). 


\subsubsection{Substrate screening for effective utilization of agro waste}

The selection of cheap and easily available agro residue for the production is useful to make production economically feasible and contains lignin which is a natural inducer for the laccase production ${ }^{(27,28)}$. Among the different substrates like wheat bran, rice bran and sugarcane bagasse, orange peelings, rice husk and tobacco leaves screened in the submerged fermentation, laccase production was maximum in medium containing orange peel as a substrate $(65.1 \mathrm{U} / \mathrm{mL})$ followed by wheat bran $(31.0$ $\mathrm{U} / \mathrm{mL}$ ) and sugarcane bagasse $(18.5 \mathrm{U} / \mathrm{mL})$ on $96 \mathrm{~h}$ of incubation [ Figure 4]. The laccase production obtained with orange peelings is significantly different than all substrate studied $(\mathrm{F}=500.4, \mathrm{p}$ value $=\mathrm{p}<0.0001$ for ANOVA). Rice bran has been reported as a suitable substrate for higher yields of laccase production due to the presence of higher lignin content (up to 12\%) in rice ${ }^{(21)}$. In present study, rice bran does not support laccase production even though with high level of lignin content. Instead of rice bran, orange peelings showed best laccase production by P. pinodella BL3/4 probably due to the presence of high level of pectin, cellulose and soluble carbohydrates ${ }^{(27)}$. Results of present study supports the earlier report on use of orange peelings for maximum laccase production by Pleurotus ostreatus ${ }^{(29)}$.

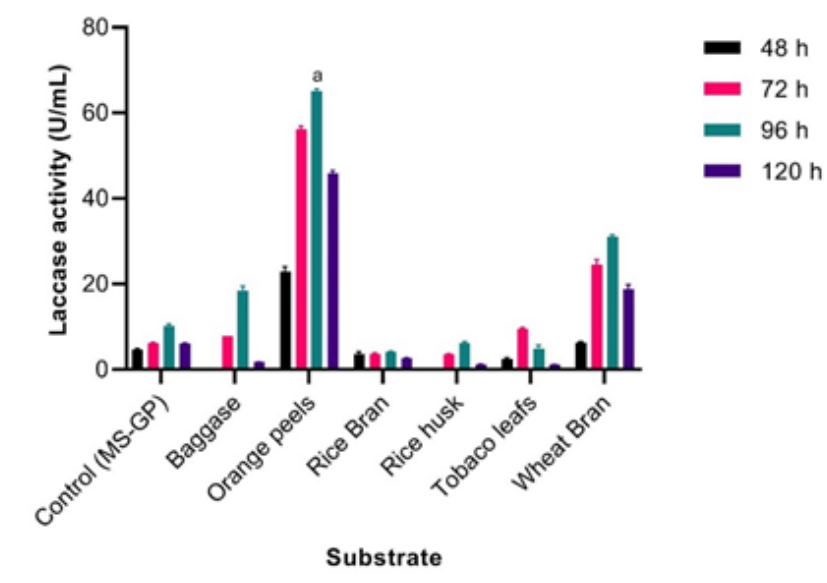

Fig 4. Effect of different agro residue as a substrate on laccase production. ANOVA: $p$ value $=p<0.0001$, $p$ value summary based on Tukey's multiple comparison tests $={ }^{\text {a }}$ highly significant with respect to the control (MS-GP medium).

\subsubsection{Optimization of $\mathrm{pH}$ and temperature}

Optimum $\mathrm{pH}$ for the maximum production of laccase by $P$. pinodella BL3/4 was studied by varying the $\mathrm{pH}$ of culture medium from 4.0 to 8.0 (at an interval of $\mathrm{pH} 0.5$ ). The results showed that peroxidase production within $\mathrm{pH} 4.0-8.0$ was significantly different $(\mathrm{F}=213.6$, $\mathrm{p}$ value $=\mathrm{p}<0.0001$ for ANOVA $)$. However, the optimal activity is mainly obtained in the $\mathrm{pH}$ range of 5.57.5. The maximum laccase production $(66.7 \mathrm{U} / \mathrm{mL})$ was obtained at $\mathrm{pH} 6.0$ on the $96 \mathrm{~h}$ of incubation [ Figure 5]. The present study shows that, $\mathrm{pH}$ below 4.5 does not support the growth of fungi, hence laccase activity also not detected and whereas growth of fungi was diminished at $\mathrm{pH}$ above 7.5 hence least enzyme activity was obtained. Fungal laccases are reported to be generally active at low $\mathrm{pH}$ values $(\mathrm{pH} 3.0-5.0)^{(30)}$. However, results of present study disagree with results reported earlier with maximum enzyme production at $\mathrm{pH} 4.5^{(30,31)}$.

Incubation temperature is the most crucial parameter for fungal growth as well as for the optimum metabolic activity of microorganism especially for the production of enzymes. Generally, the fermentation temperature between $25^{\circ} \mathrm{C}$ and $30^{\circ} \mathrm{C}$ is optimal for fungal laccase production ${ }^{(19)}$. The results revealed that laccase production differs significantly $(\mathrm{F}=162.6, \mathrm{p}$ value $=$ $\mathrm{p}<0.0001$ for ANOVA) across the investigated temperatures $\left(20-40^{\circ} \mathrm{C}\right)$ [ Figure 6]. The maximum laccase activity was detected at a temperature of $30^{\circ} \mathrm{C}$ on $96 \mathrm{~h}$ of incubation, which is incongruence with a earlier report where the maximum laccase is produced at $30^{\circ} \mathrm{C}$ by Aspergillus flavus PUF ${ }^{(32)}$. Higher temperatures lead to the denaturation of the key enzymes. However, a lower temperature of $20^{\circ} \mathrm{C}$ did not support the growth of fungi, thus leading to lower enzyme production.

\subsubsection{Optimization of Carbon Supplements}

Carbohydrates are preferable source of carbon for fungal biomass as well as enzyme production. Glucose is proven an effective carbon source for the production of laccase by fungi ${ }^{(33)}$. Thus, laccase production was studied in presence of different types of 


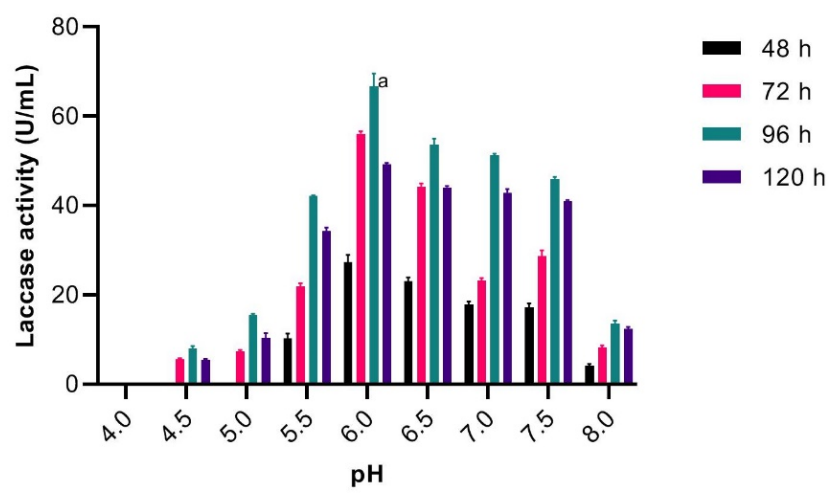

Fig 5. Effect of $\mathrm{pH}$ of medium on laccase production. ANOVA: $\mathrm{p}$ value $=\mathrm{p}<0.0001, \mathrm{p}$ value summary based on Tukey's multiple comparison tests $={ }^{a}$ highly significant with respect to the control ( $\left.\mathrm{pH} 5.5\right)$.

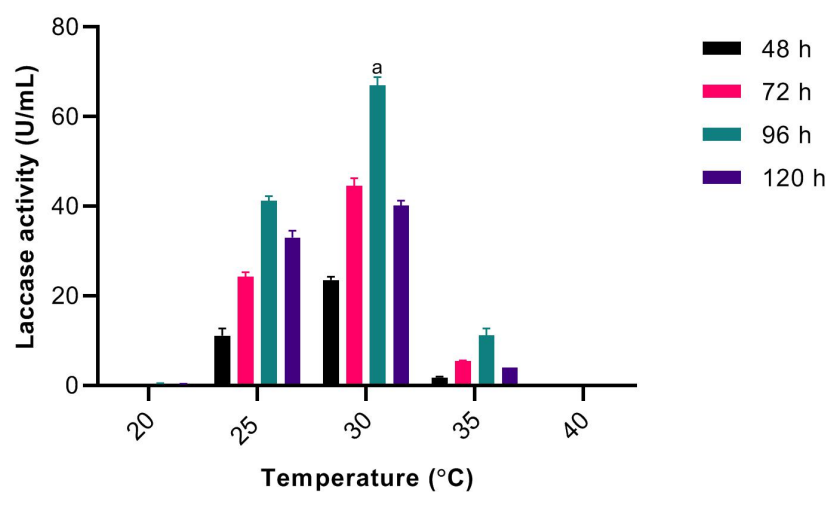

Fig 6. Effect of temperature on laccase production. ANOVA: $\mathrm{p}$ value $=\mathrm{p}<0.0001, \mathrm{p}$ value summary based on Tukey's multiple comparison tests $={ }^{\text {a }}$ highly significant with respect to the control $\left(25^{\circ} \mathrm{C}\right)$.

carbohydrate like glucose, sucrose and soluble starch $(0.5 \%)$. Laccase production was maximum $(65.93 \mathrm{u} / \mathrm{ml})$ in the presence of glucose $(1.0 \%)$ followed by sucrose $(59.0 \mathrm{u} / \mathrm{ml})$ and starch $(49.0 \mathrm{u} / \mathrm{ml})$ on $96 \mathrm{~h}$ of incubation. The laccase production by $P$. pinodella BL3/4 differs significantly $(\mathrm{F}=44.36$, $\mathrm{p}$ value $=\mathrm{p}<0.0001$ for ANOVA $)$ with different carbon source [ Figure 7]. Earlier studies have revealed that although glucose supports the highest specific growth rate, specific rate of enzyme production was significantly reduced ${ }^{(32)}$. This is not supported by the findings of the present study. Laccase production was gradually increased with the increase of glucose concentration up to a certain level (2.0\%), above which enzyme production was markedly decreased.

\subsubsection{Optimization of Nitrogen supplements}

Replacement of peptone $(0.5 \%)$ with other organic and inorganic nitrogen sources significantly reduced laccase production by P. pinodella BL3/4 [ Figure 8] $(\mathrm{F}=57.34, \mathrm{p}$ value $=\mathrm{p}<0.0001$ for ANOVA $)$. This is may be due to low growth in the presence of other nitrogen sources. A similar result has also been reported from Trametes pubescens MB89 ${ }^{(34)}$. Present finding does not support the report on use of yeast extract for improved laccase production ${ }^{(13)}$. The present study showed that decreasing peptone concentration below $0.5 \%$, the fungal growth was dramatically reduced, hence, reduction in laccase activity. The study thus confirmed that, laccase synthesis increased at higher peptone concentration due to improved fungal growth.

\subsubsection{Optimization of agitation rate}

Under submerged fermentation, sufficient oxygen requirement of any aerobic microorganism is fulfilled by optimizing shaking speed. The influence of agitation rate on laccase production by $P$. pinodella BL3/4 is significantly differs across agitation rate 


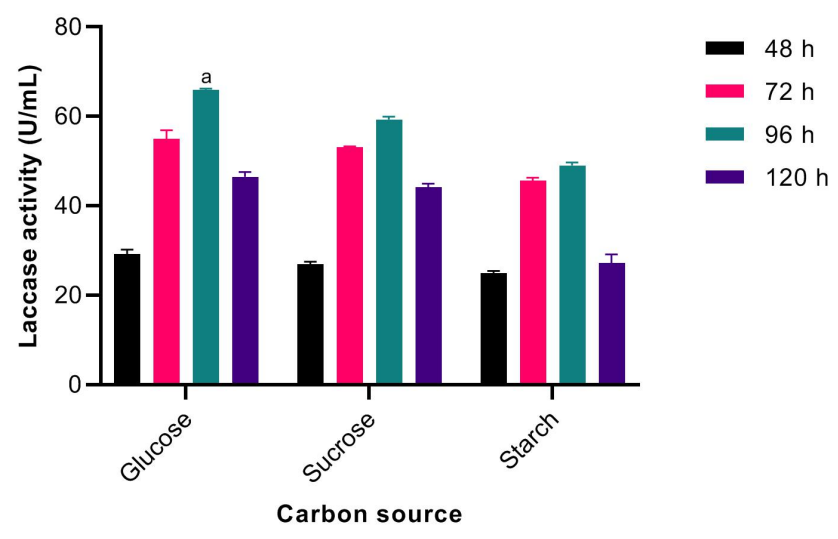

Fig 7. Effect of different carbon supplement on laccase production. ANOVA: $p$ value $=p<0.0001$, $p$ value summary based on Tukey's multiple comparison tests $={ }^{a}$ highly significant with respect to the sucrose and starch.

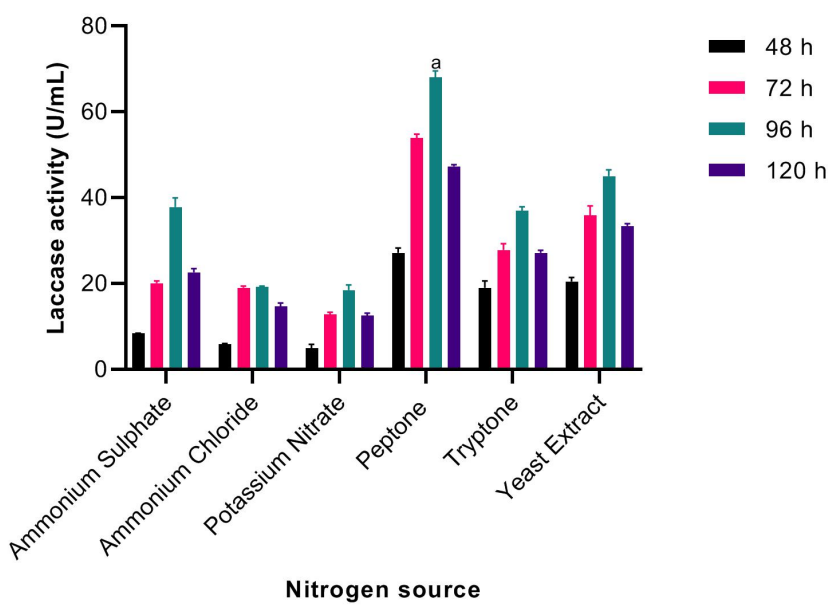

Fig 8. Effect of different nitrogen on laccase production. ANOVA: $p$ value $=p<0.0001$, $p$ value summary based on Tukey's multiple comparison tests $={ }^{a}$ highly significant with respect to the other nitrogen sources used in the study.

studied $(\mathrm{F}=59.42$, $\mathrm{p}$ value $=\mathrm{p}<0.0001$ for ANOVA $)$. Maximum laccase activity was obtained at $150 \mathrm{rpm}$ on $96 \mathrm{~h}$ of incubation [ Figure 9]. Study had revealed that laccase production could be improved by providing optimum agitation to the medium to improve aeration ${ }^{(28)}$. The agitation causes better aeration in the well agitated flasks that was essential for the growth and enzyme production.

\subsection{Effect of inducers and Copper ion concentration}

Laccase production can be greatly enhanced by incorporating suitable inducer in the medium. Different compounds such as phenolic and non-phenolic substrates can act as inducers. In the present study laccase production by P. pinodella BL3/4 was evaluated in the presence of seven different inducer compounds (o-anisidine, $\mathrm{p}$-anisidine, catechol, guaicol, pyrogallol, gallic acid, and absolute ethanol). Among all, absolute ethanol $(88.0 \mathrm{u} / \mathrm{ml}$ on $96 \mathrm{~h}$ of incubation.) followed by catechol $(71.0 \mathrm{U} / \mathrm{mL}$ on $96 \mathrm{~h}$ of incubation.) was found to be efficient laccase inducer than the control flask [ Figure 10]. The effect of absolute ethanol and catechol on laccase production was significantly different from the control flask $(\mathrm{F}=480.9, \mathrm{p}$ value $=\mathrm{p}<0.0001$ for ANOVA). Furthermore, different concentrations of copper in the range of $2-500 \mathrm{mM}$ were also studied. Maximum laccase production was obtained at $10 \mu \mathrm{M}$ copper concentration $(99.0 \mathrm{U} / \mathrm{mL})$ which significantly differ across the concentration of copper studied ( $\mathrm{p}$ value $=\mathrm{p}<0.0001$ for Student's $\mathrm{t}$ test $)$ [Figure 11]. Greater than $10 \mathrm{mM}$ copper repress enzyme production. Present findings 


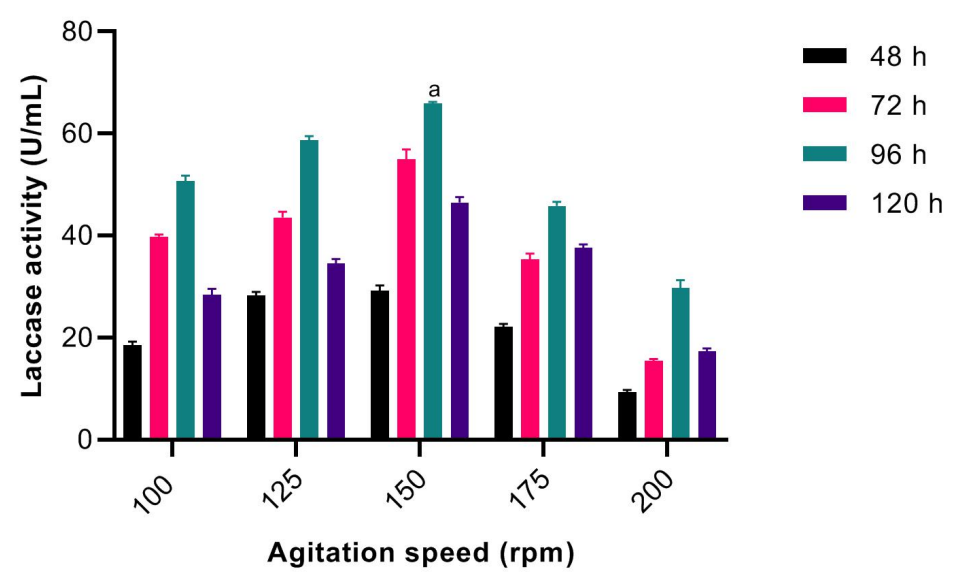

Fig 9. Effect of agitation speed on laccase production. ANOVA: $p$ value $=p<0.0001, p$ value summary based on Tukey's multiple comparison tests $={ }^{\text {a }}$ highly significant with respect to the control $(100 \mathrm{rpm})$.

did not support recent report on Trichoderma muroiana IS1037 ${ }^{(31)}$. High concentration of copper acts as an inhibitor of fungal growth which is a key component in many fungicides ${ }^{(11)}$.

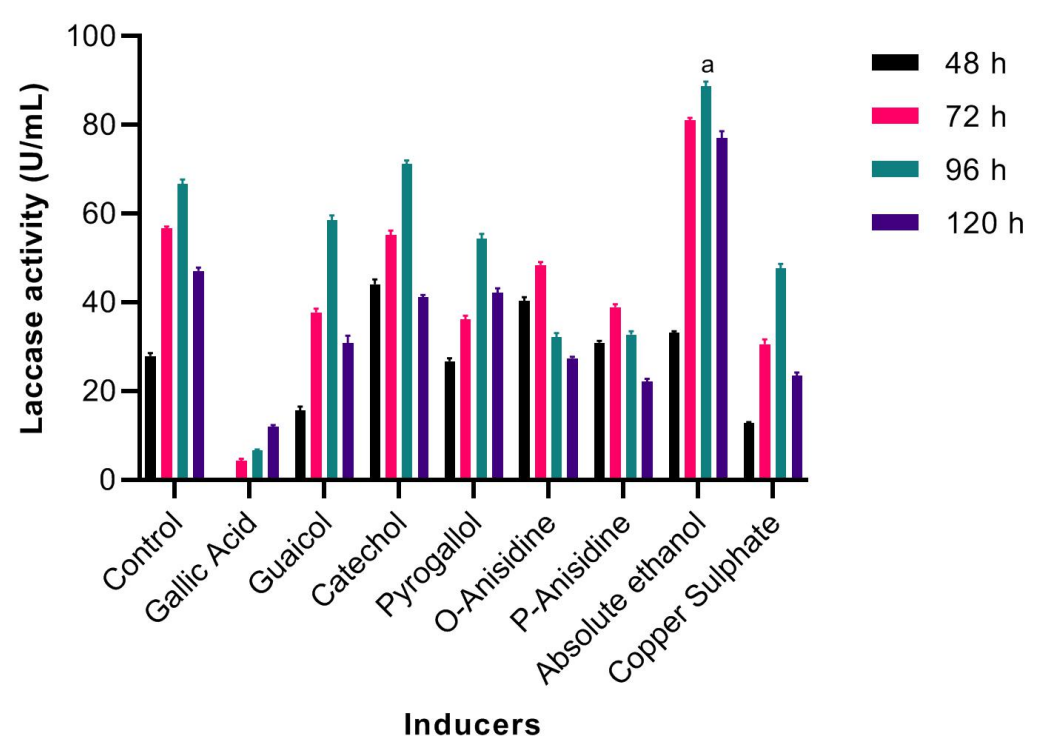

Fig 10. Effect of inducers on laccase production. ANOVA: $p$ value $=p<0.0001, p$ value summary based on Tukey's multiple comparison tests $={ }^{\mathrm{a}}$ highly significant with respect to the control.

\subsection{Time course study for maximum Laccase production}

Time course study of laccase production by $P$. pinodella BL-3/4 was carried out prior and after the medium optimization in SmF. Laccase production was increased 18 fold compared to that of unoptimized medium $(5.5 \mathrm{U} / \mathrm{mL})$ with the maximum production of $98.6 \mathrm{U} / \mathrm{mL}$ on $96 \mathrm{~h}$ of incubation [ Figure 12]. Maximum laccase production has been reported on $96 \mathrm{hrs}$ of incubation ${ }^{(17,18,31)}$. Use of single parameter at a time approach for optimization of cultural conditions has been reported earlier for efficient laccase production ${ }^{(35,36)}$. 


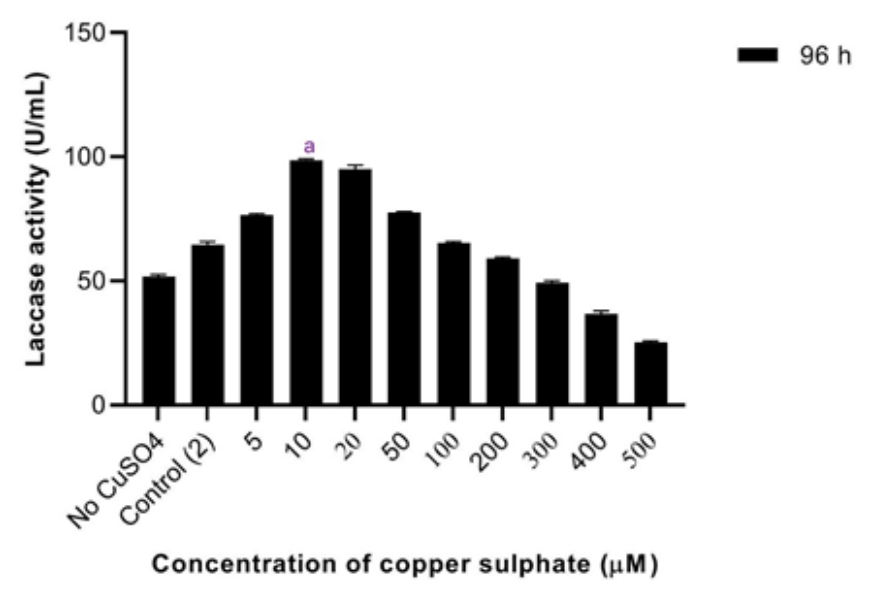

Fig 11. Effect of different concentration of copper sulphate on laccase production. Student's test: $p$ value $=p<0.0001, p$ value summary $={ }^{a}$ highly significant with respect to the control, R squared $=0.8966$.

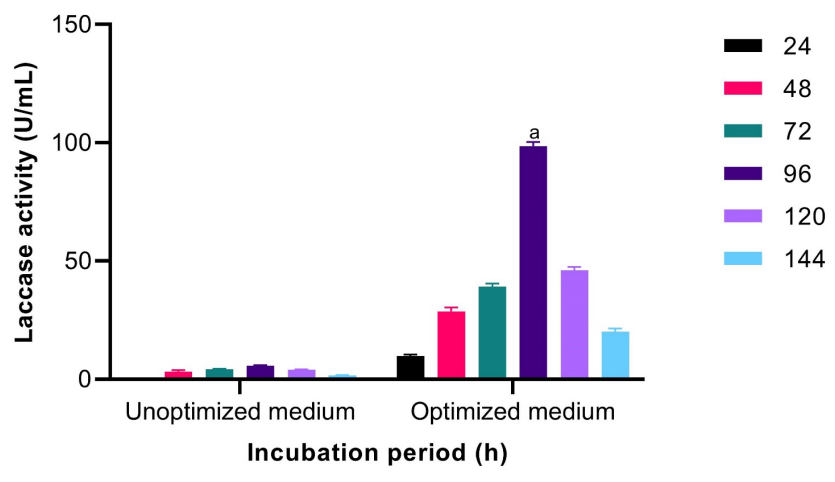

Fig 12. Time course study of laccase production by Peyronellaea pinodella BL-3/4 with unoptimized and optimized medium. ANOVA: $\mathrm{F}=$ 840.7, $\mathrm{p}$ value $=\mathrm{p}<0.0001, \mathrm{p}$ value summary based on Tukey's multiple comparison tests $={ }^{\mathrm{a}}$ highly significant with respect to the unoptimized medium.

\section{Conclusion}

Qualitative screening of laccase producing ascomycetes was successfully done using non phenolic lignin model compounds namely ABTS, guaicol and syringaldazine. The novelty regarding the present study is that, to date the isolated fungal strain has not been explored for laccase production and its optimization. The present study revealed that fungal isolate Peyronellaea pinodella BL-3/4 is a novel ascomycetes in laccase production. Optimization of cultural conditions by single parameter at a time approach resulted in to the maximum production of laccase at a $\mathrm{pH} 6.0$, temperature of $30^{\circ} \mathrm{C}$, inoculum size of 5 mycelial plugs, agitation speed of $150 \mathrm{rpm}$ and at $96 \mathrm{~h}$ of incubation period. Maximum laccase production by $P$. pinodella BL-3/4 at $96 \mathrm{~h}$ of incubation suggests that laccase is produced at early stages of incubation in comparison with basidiomycetes fungi, which can satisfy huge demand of this old enzyme in future. Laccase production increased in presence of orange peelings from 10.4 to $65.1 \mathrm{U} / \mathrm{mL}$. It proves that an orange peeling is promising substrate in laccase production as well as other ligninolytic enzymes in the future. Instead of aromatic inducers, small amount $(10 \mu \mathrm{M})$ of copper sulphate in medium enhanced laccase yield by $P$. pinodella BL-3/4 strain. 


\section{Acknowledgements}

The authors are thankful to the Shri M. M. Patel Institute of Sciences and research, Gandhinagar, Gujarat, India for providing laboratory facilities. The authors also wish to acknowledge Gujarat State Biotechnology Mission, Gandhinagar, and Gujarat, India for sequencing and identification of fungal isolate.

\section{References}

1) Dashtban M, Schraft H, Qin W. Fungal Bioconversion of Lignocellulosic Residues; Opportunities \& Perspectives. International Journal of Biological Sciences. 2009;5(6):578-595. doi:10.7150/ijbs.5.578.

2) Kosman DJ. Multicopper oxidases: a workshop on copper coordination chemistry, electron transfer, and metallophysiology. JBIC Journal of Biological Inorganic Chemistry. 2010;15(1):15-28. doi:10.1007/s00775-009-0590-9.

3) Zheng F, Cui BK, Wu XJ, Meng G, Liu HX, Si J. Immobilization of laccase onto chitosan beads to enhance its capability to degrade synthetic dyes. International Biodeterioration and Biodegradation. 2016;110:69-78. doi:10.1016/j.ibiod.2016.03.004.

4) Aguila SA, Shimomoto D, Ipinza F, Bedolla-Valdez ZI, Romo-Herrera J, Contreras OE, et al. A biosensor based onCoriolopsis gallicalaccase immobilized on nitrogen-doped multiwalled carbon nanotubes and graphene oxide for polyphenol detection. Science and Technology of Advanced Materials. 2015;16(5):055004-055004. doi:10.1088/1468-6996/16/5/055004.

5) Dhouib A, Hamza M, Zouari H, Mechichi T, Hmidi R, Labat M, et al. Screening for Ligninolytic Enzyme Production by Diverse Fungi from Tunisia. World Journal of Microbiology and Biotechnology. 2005;21(8-9):1415-1423. doi:10.1007/s11274-005-5774-Z.

6) Agrawal K, Chaturvedi V, Verma P. Fungal laccase discovered but yet undiscovered. Bioresources and Bioprocessing. 2018;5(4):1-12. doi:10.1186/s40643018-0190-z.

7) Yang J, Li W, Ng TB, Deng X, Lin J, Ye X. Laccases: production, expression regulation, and applications in pharmaceutical biodegradation. Frontiers in microbiology. 2017;8:1-24. doi:10.3389/fmicb.2017.00832.

8) Hattori M, Konishi H, Tamura Y, Konno K, Sogawa K. Laccase-type phenoloxidase in salivary glands and watery saliva of the green rice leafhopper, Nephotettix cincticeps. Journal of Insect Physiology. 2005;51(12):1359-1365. doi:10.1016/j.jinsphys.2005.08.010.

9) Songulashvili G, Flahaut S, Demarez M, Tricot C, Bauvois C, Debaste F, et al. High yield production in seven days of Coriolopsis gallica 1184 laccase at 50 L scale; enzyme purification and molecular characterization. Fungal Biology. 2016;120(4):481-488. doi:10.1016/j.funbio.2016.01.008.

10) Sadhasivam S, Savitha S, Swaminathan K, Lin FH. Production, purification and characterization of mid-redox potential laccase from a newly isolated Trichoderma harzianum WL1. Process Biochemistry. 2008;43(7):736-742. doi:10.1016/j.procbio.2008.02.017.

11) Revankar MS, Lele SS. Enhanced production of laccase using a new isolate of white rot fungus WR-1. Process Biochemistry. 2006;41(3):581-588. doi:10.1016/j.procbio.2005.07.019.

12) Banerjee UC, Vohra RM. Production of laccase byCurvularia sp. Folia Microbiologica. 1991;36(4):343-346. doi:10.1007/bf02814506.

13) Zhu C, Bao G, Huang S. Optimization of laccase production in the white-rot fungusPleurotus ostreatus(ACCC 52857) induced through yeast extract and copper. Biotechnology \& Biotechnological Equipment. 2016;30(2):270-276. Available from: https://dx.doi.org/10.1080/13102818.2015.1135081. doi:10.1080/13102818.2015.1135081.

14) Hao J, Song F, Huang F, Yang C, Zhang Z, Zheng Y, et al. Production of laccase by a newly isolated deuteromycete fungus Pestalotiopsis sp. and its decolourisation of azo dye. Journal of Industrial Microbiology and Biotechnology. 2007;34:233-240. doi:10.1007/s10295-006-0191-3.

15) Elshafei AM, Hassan MM, Haroun BM, Elsayed MA, Othman AM. Optimization of Laccase Production from $<\mathrm{i}>$ Penicillium martensii $</ \mathrm{i}>\mathrm{NRC} 345$. Advances in Life Sciences. 2012;2(1):31-37. doi:10.5923/j.als.20120201.05.

16) Feng X, Chen H, Xue D, Yao S. Enhancement of Laccase Activity by Marine-derived Deuteromycete Pestalotiopsis sp. J63 with Agricultural Residues and Inducers. Chinese Journal of Chemical Engineering. 2013;21(10):1182-1189. doi:10.1016/s1004-9541(13)60567-4.

17) Patel JR, Bhaskaran L. Screening of novel ascomycetes for the production of laccase enzyme using different lignin model compounds. International Journal of Pharma and Bio Sciences. 2016;7(4):B452-8. doi:10.22376/ijpbs.2016.7.4.b452-458.

18) Myasoedova NM, Renfeld ZV, Podieiablonskaia EV, Samoilova AS, Chernykh AM, Classen T, et al. Novel laccase-producing ascomycetes. Microbiology. 2017;86(4):503-511. doi:10.1134/s0026261717030110.

19) Brijwani K, Rigdon A, Vadlani PV. Fungal Laccases: Production, Function, and Applications in Food Processing. Enzyme Research. 2010;2010:1-10. doi:10.4061/2010/149748.

20) Pang S, Wu Y, Zhang X, Li B, Ouyang J, Ding M. Immobilization of laccase via adsorption onto bimodal mesoporous Zr-MOF. Process Biochemistry. 2016;51(2):229-239. doi:10.1016/j.procbio.2015.11.033.

21) Niladevi KN, Prema P. Effect of inducers and process parameters on laccase production by Streptomyces psammoticus and its application in dye decolourization. Bioresource Technology. 2008;99(11):4583-4589. doi:10.1016/j.biortech.2007.06.056.

22) Abdel-Azeem AM. Biodiversity of laccase producing fungi in Egypt. Mycosphere. 2012;3(6):900-920. doi:10.5943/mycosphere/3/6/4.

23) Alfarra HY, Hnhm O. A lignolytic fungi with laccase activity isolated from malaysian local environment for phytochemical transformation purposes. International Research Journal of Biological Sciences. 2013;2(2):1-6. doi:10.ISCA-IRJBS-2012-226.

24) Harkin JM, Obst JR. Syringaldazine, an effective reagent for detecting laccase and peroxidase in fungi. Experientia. 1971;29:381-87. doi:10.1007/BF01926734.

25) Niku-Paavola ML, Raaska L, Itävaara M. Detection of white-rot fungi by a non-toxic stain. Mycological Research. 1990;94(1):27-31. doi:10.1016/s09537562(09)81260-4.

26) Patel H, Gupte A, Gupte S. Effect of different culture conditions and inducers on production of laccase by a basidiomycete's fungal isolate Pleurotus ostreatus HP-1 under solid state fermentation. Bioresources. 2009;4(1):268-84. doi:10.15376/biores.4.1.268-284.

27) Rosales E, Couto SR, Sanromán MA. Increased laccase production by Trametes hirsuta grown on ground orange peelings. Enzyme and Microbial Technology. 2007;40:1286-1290. doi:10.1016/j.enzmictec.2006.09.015.

28) Chhaya RS, Modi HA. Comparative study of laccase production by Streptomyces chartreusis in solid state and submerged fermentation. Indian Journal of Fundamental and Applied Life Sciences. 2013;3(1):73-84. Available from: http://www.cibtech.org/jls.htm.

29) Ire F, Ahuekwe E. Production of Fungal Laccase Using Orange Peelings as Substrate by Submerged Static Fermentation. British Microbiology Research Journal. 2016;15(5):1-19. doi:10.9734/bmrj/2016/27257. 
30) More SS, S RP, K P, M S, Malini S, M VS. Isolation, Purification, and Characterization of Fungal Laccase fromPleurotussp. Enzyme Research. 2011;2011:1-7. doi:10.4061/2011/248735.

31) Jaber SM, Shah UKM, Asaari AZM, Ariff AB. Optimization of Laccase Production by Locally Isolated Trichoderma muroiana IS1037 Using Rubber Wood Dust as Substrate. BioResources. 2017;12(2):3834-49. doi:10.15376/biores.12.2.3834-3849.

32) Ghosh P, Ghosh U. Statistical optimization of laccase production by Aspergillus flavus PUF5 through submerged fermentation using agro-waste as cheap substrate. Acta Biologica Szegediensis. 2017;61(1):25-33. Available from: http://www2.sci.u-szeged.hu/ABS.

33) Sivakami V, Ramachandran B, Srivathsan J, Kesavaperumal G, Smily B, Kumar M, et al. Production and optimization of laccase and lignin peroxidase by newly isolated Pleurotus ostreatus LIG 19. Journal of Microbiology and Biotechnology Research. 2012;2(6):875-81. Available from: http: //scholarsresearchlibrary.com/archive.html.

34) Strong PJ. Improved Laccase Production byTrametes pubescensMB89 in Distillery Wastewaters. Enzyme Research. 2011;2011(1):1-8. doi:10.4061/2011/379176.

35) Afreen S, Anwer R, Singh RK, Fatma T. Extracellular laccase production and its optimization from Arthrospira maxima catalyzed decolorization of synthetic dyes. Saudi Journal of Biological Sciences. 2016;25(7):1446-1453. doi:10.1016/j.sjbs.2016.01.015.

36) Chenthamarakshan A, Parambayil N, Miziriya N, Soumya PS, Lakshmi MSK, Ramgopal A, et al. Optimization of laccase production from Marasmiellus palmivorus LA1 by Taguchi method of Design of experiments. BMC Biotechnology. 2017;17(1):12-12. Available from: https://dx.doi.org/10.1186/s12896017-0333-x. doi:10.1186/s12896-017-0333-x. 